\title{
Metabolic and Inflammatory Markers in Overweight and Obese 6 to 12 y old Mexican School Children
}

\author{
F. E. Gomez ${ }^{1}$, A. Avila-Curiel ${ }^{2}$, C. Galindo-Gomez ${ }^{2}$, L. Juarez-Martinez ${ }^{2}$, J. Flores-Sanchez ${ }^{2}$, \\ E. Diaz-Diaz ${ }^{3}$ and C. Sosa Alvarado ${ }^{1}$ \\ ${ }^{1}$ Fisiología de la Nutrición, ${ }^{2}$ Dirección de Nutrición and ${ }^{3}$ Endocrinología, Instituto Nacional de Ciencias Médicas y \\ Nutrición Salvador Zubirán, Vasco de Quiroga 15, Tlalpan 14000, México, D.F. Mexico
}

Obesity has become a worldwide pandemic. Governments around the globe are taking sanitary measures in order to reduce or prevent it. Children are becoming overweight and obese at earlier ages, which could predispose them to chronic diseases, such as diabetes, hypertension and metabolic syndrome later in life. Obesity has been described as a "chronic state of low-grade inflammation" characterized by an increase in proteins secreted by the adipose tissue (adipokines), such as leptin, interleukin-6 (IL-6) and TNF- $\alpha$, while the antinflammatory adiponectin is reduced.

We studied 1500 children aged 6 to 12 years from March to April 2012, in 14 Primary Schools in the State of Mexico. Anthropometric assessment included height, weight and BMI adjusted by age according to the International Obesity Task Force and children were classified as "normal weight" ( $\mathrm{N}, n=150)$, "overweight" (Ov, $n=225)$ or "obese" $(\mathrm{Ob}, n=1125)$. Peripheral blood was obtained to quantify biochemical and metabolic markers (glucose, insulin, triglycerides, total cholesterol, LDL and HDL), adipokines (leptin, adiponectin, TNF- $\alpha$ and IL-6) and proinflammatory proteins (IL-8).

Although still in the normal range, serum levels of glucose in Ov and Ob children (average, 86.4 and $88.6 \mathrm{mg} / \mathrm{dL}$, respectively) were statistically higher than in $\mathrm{N}$ children $(84.9 \mathrm{mg} / \mathrm{dL})$ which was due to an increase in insulin $(\mathrm{pg} / \mathrm{mL}, \mathrm{N}=5.8, \mathrm{Ov}=10.8$ and $\mathrm{Ob}=13.5)$. There was also an increase in triglycerides (in $\mathrm{mg} / \mathrm{dL}, \mathrm{N}=89.9, \mathrm{Ov}=136.5, \mathrm{Ob}=151.3$ ), cholesterol (in $\mathrm{mg} / \mathrm{dL}, \mathrm{N}=168.5, \mathrm{Ov}=172.0$, $\mathrm{Ob}=181.7$ ), LDL (in $\mathrm{mg} / \mathrm{dL}, \mathrm{N}=81.2, \mathrm{Ov}=88.8, \mathrm{Ob}=96.1)$, leptin $(\mathrm{pg} / \mathrm{mL}, \mathrm{N}=3.9, \mathrm{Ov}=11.1, \mathrm{Ob}=17.5), \mathrm{TNF}-\alpha(\mathrm{pg} / \mathrm{mL}, \mathrm{N}=2.1$, $\mathrm{Ov}=2.2, \mathrm{Ob}=2.5)$ and $\mathrm{IL}-6(\mathrm{pg} / \mathrm{mL}, \mathrm{N}=4.4, \mathrm{Ov}=5.9, \mathrm{Ob}=4.0)$. On the other hand, there was a reduction in HDL $(\mathrm{mg} / \mathrm{dL}, \mathrm{N}=46.5$, $\mathrm{Ov}=38.1, \mathrm{Ob}=38.0)$, adiponectin $(\mu \mathrm{g} / \mathrm{mL}, \mathrm{N}=28.6, \mathrm{Ov}=19.5, \mathrm{Ob}=18.2)$ and $\mathrm{IL}-8(\mathrm{pg} / \mathrm{mL}, \mathrm{N}=3.1, \mathrm{Ov}=2.0, \mathrm{Ob}=2.3)$.

These results show that even at an early age, overweight and obese young school children (aged 6 to 12 years) develop the same metabolic disturbances previously described only in adult obese people. Metabolic and proinflammatory states are clearly developed in overweight and obese young children. What is more striking is that overweight school children clearly show a trend towards an inflammatory state. The increase in metabolic and proinflammatory markers in young children clearly suggests that preventive measures are necessary to stop the pandemic of overweight and obesity in Mexico, and all over the world. 